\title{
Phyotherapeutic Properties of Urfa Pistachio Nuts (Pistacia vera L.)
}

\author{
Urfa Fıstığının (Pistacia vera L.) Fitoterapik Özellikleri
}

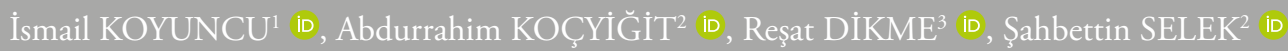 \\ ${ }^{1}$ Department of Medical Biochemistry, Harran University School of Medicine, Şanlıurfa, Turkey \\ 2Department of Medical Biochemistry, Bezmialem Vakif University School of Medicine, İstanbul, Turkey \\ ${ }^{3}$ Department of Medical Biology and Genetics, Harran University School of Medicine, Şanlıurfa, Turkey
}

\section{ABSTRACT}

According to recent studies, the Urfa pistachio nut (Pistacia vera L.) is a rich source of phenolic components, with a high level of the three antioxidant substances of gallic acid, catechin, and epicatechin present together. The pistachio nut, which is in the top 50 foodstuffs with the highest antioxidant potential, is the only edible nut containing anthocyanin, which is the richest and has most variations of water and fat-soluble antioxidants. The pistachio nut also contains important bioactive polyphenol components, such as transreservatrol and isoflavones, which have anti-cancer potential. Some forms of the Pistachio species, including the Urfa pistachio nut, are used by the general population to improve the gastrointestinal, liver, urinary tract, and respiratory tract disorders and for various other purposes such as aphrodisiac, antiseptic, and antihypertensive effects. In some studies, it has been determined that the pistachio nut is beneficial in the continuation of mechanisms that provide maintenance of body health, such as anti-inflammatory activity, glycemic control, and endothelial functions, and it has also been shown to prevent the oxidation of low-density lipoprotein cholesterol and to have a protective role against chronic diseases such as cancer and cardiovascular disease. With a potassium content of 10.05 $\mathrm{mg} / \mathrm{gram}$, which is higher than other types of peanut, the sodium content of the pistachio nut may play a role in balancing the blood pressure by reducing the need for salt. This review is of importance in respect of the evaluation of the positive effect on several diseases of the kernel and particularly the shell extract of the pistachio nut.

Keywords: Pistacia vera L., phytotherapeutic, Urfa pistachio nuts

\section{öz}

Son yıllarda yapılan çalışmalara göre Urfa fistığı (Pistacia vera L.) fenolik bileşiklerin zengin bir kaynağı olup, gallik asit, kateşin ve epikateşin gibi yüksek derecede antioksidan üç maddeyi bir arada bulundurmaktadır. Antioksidan potansiyeli en yüksek ilk elli gıda arasında yer alan Urfa fistığı ağaç yemişleri arasında suda ve yağda çözünen antioksidanlar açısından en zengin ve en çok çeşitliliğe sahip olup antosiyanin içeren tek yenilebilir kuruyemiş olma özelliğine sahiptir. Urfa fistığı; antikanser potansiyeline sahip isoflavonlar ve transresveratrol gibi önemli bioaktif polifenol bileşikler de içermektedir. Urfa fıstığının dâhil olduğu Pistacia cinsinin bazı türleri halk arasında diş, gastrointestinal, karaciğer, idrar yolu ve solunum yolu rahatsızlıklarının iyileştirilmesinin yanında ayrıca afrodizyak, antiseptik ve antihipertansif etkilerinden dolayı çeşitli amaçlarla kullanılmaktadır. Birçok çalışmada Urfa fıstığının anti-inflamatuar aktivite, glisemik kontrol ve endotel fonksiyonu gibi vücut sağlığının idamesini sağlayan mekanizmaların devam etmesine yardımcı olduğu, ayrıca; aterogenezde LDL kolesterolünün okside olmasını engellediği, kanser ve kardiyovasküler hastalık gibi kronik hastalıklara karşı koruyucu rol oynayabildiği tespit edilmiştir. Diğer fistık türleri arasında 10,05 $\mathrm{mg}$ /gram ile en yüksek potasyum içeriğine sahip olan Urfa fistığı sodyum içerikli tuz ihtiyacını azaltarak tansiyon üzerinde dengeleyici bir rol oynayabilmektedir. Tohum ve özellikle dış kabuk ekstresinin birçok hastalığa olumlu etkisi olan Urfa fistığının özellikle dış kabuğunun değerlendirilmesi açısından bu derleme önemlidir.

Anahtar Kelimeler: Pistacia vera L, fitoterapi, Urfa fistığ

\section{Introduction}

According to archaeological records, the first human consumption of peanuts occured in $7000 \mathrm{BC}$ (1). The oldest type of flowering peanut is the Urfa pistachio nut (Pistacia vera L.), which is a member of the cashew family (Anacardiaceae), originating from the Middle East. The Urfa pistachio nut, which is the only type of the Pistacia species that is farmed and used as a foodstuff, consists of an edible kernel, a hard outer shell and a softer shell. Currently, Urfa pistachio nuts are grown mostly in Iran, the United States, and Turkey. In Turkey, the majority are produced in the provinces of Gaziantep, Şanlıurfa, and Siirt.

Some types of the Pistacia species (P. lentiscus, P. terebinthus, P. atlantica, and P. khinjuk), including the Urfa pistachio nut, are used by the general population for various purposes, such as the improvement of gastrointestinal, liver, urinary tract, and reCite this article as: Koyuncu İ, Koçyiğit A, Dikme R, Selek Ş. Phyotherapeutic Properties of Urfa Pistachio Nuts (Pistacia vera L.). Bezmialem Science 2018; 6(3): 200-5. 
spiratory tract disorders and because of its aphrodisiac, antiseptic, and antihypertensive effects $(2,3)$. Due to the phenolic and flavonoid components of Pistacia species, they have antimutagenic, antimicrobial, anti-inflammatory, anti-cancer, and antioxidant potential (3). As a source of rich phenolic components, the Urfa pistachio nut is accepted as a "unique functional food" and is in the top 50 foods with antioxidant potential (3-5).

Of all tree nuts, the Urfa pistachio nut is the richest in and has the most variations of water and fat-soluble antioxidants (6), is the only edible nut containing anthocyanin $(7,8)$, and contains important bioactive polyphenols such as transreservatrol and isoflavones, which have anti-cancer potential (9). All the studies that have been made on the Urfa pistachio nut can be classified in four categories:

\section{1) Experimental Clinical Studies}

Due to the mono-unsaturated fats, vitamins, and antioxidants contained in the Urfa pistachio nut, several studies have determined that it is beneficial in providing maintenance of anti-inflammatory activity, glycemic control, and endothelial function, that it prevents the oxidation of low-density lipoprotein (LDL) cholesterol in atherogenesis and may have a protective role against chronic diseases such as cancer and cardiovascular diseases $(1,10-12)$.

According to studies related to cardiovascular diseases, consumption of the Urfa pistachio nut creates positive effects on cardiovascular risk factors by showing a positive effect on the blood lipid profile (13-17). It has been determined in these studies, that the Urfa pistachio nut consumption has significantly reduced total cholesterol $(13,14,16,17)$, significantly reduced LDL (16-18), and increased low-density lipoprotein by a significant degree $(14,15)$.

As a result of studies where the Urfa pistachio nut has been added to the diet, an anti-inflammatory effect has been shown on endothelial function, oxidative status, and inflammation markers, which are strong indicators of cardiovascular diseases, and it has been determined that the Urfa pistachio nut may have a significant role in the prevention of pathogenetic events that lead to cardiovascular diseases $(17,19-21)$.

According to the results of an experimental study of the consumption of Pistacia vera $L$. on a diabetic rat model, a significant decrease was observed in the Malondialdehyde (MDA) levels of the rats given the nuts and a significant increase in total antioxidant activity (TAA). These results indicated that the nut provided antioxidant protection to membrane lipids and supported the antioxidant system and showed that inclusion of the nuts in the diet could have a dose-related beneficial effect on diabetic risk factors (22).

In addition to an intense content of fatty acids that protect cardiac health, the Urfa pistachio nut has also been determined to contain many phytochemical substances such as protein, diet fibers, potassium, magnesium, vitamin $\mathrm{K}$, and $\gamma$-tochopherol and has been determined to have the highest potassium, $\gamma$-tochopherol, vitamin K, phytosterols, and xanthophyll carotenoid content of all the Pistacia species (1).

With a potassium content of $10.05 \mathrm{mg} / \mathrm{gram}$ (23-25), which is higher than other types of peanut, the sodium content of the Urfa pistachio nut may have the potential to play a role in balancing blood pressure by reducing the need for salt $(26,27)$.

In some recent studies, it has been suggested that the Urfa pistachio nut kernel and particularly the shell extract have a protective effect on the UV-B-origin skin damage, and these extracts can be successfully used as protective substances in topical cosmetic and medication formulations (28).

\section{2) Studies Related to the Content of the Urfa Pistachio Nut (P. vera $L$.) and Antioxidant Properties}

The Urfa pistachio nut, which has a high level of the three antioxidant substances of gallic acid, catechin, and epicatechin together (5), and is the richest in and has the most variations of water and fat-soluble antioxidants of all tree nuts (6), is the only edible nut containing anthocyanin $(7,8)$. As isoflavones and transreservatrol that have been determined in the Urfa pistachio nut are important bioactive polyphenols $(29,30)$, they undertake significant roles in the prevention of cancer by a chemical route (9). Due to the high amount of isoflavones (3.68 g daidzein and $3.40 \mathrm{mg}$ genistein in $100 \mathrm{gr}$ extract) (4, $30)$ and transreservatrol $(1.67 \mu \mathrm{g} / \mathrm{g})(31,32)$, the Urfa pistachio nut has been determined as the second richest foodstuff in respect of isoflavones after soya beans.

Another important component determined in the Urfa pistachio nut is flavonoid pro-anthocyanins, which are known as concentrated tannins ( $268.122 \mathrm{mg}$ in $100 \mathrm{~g}$ nuts), and these prevent lipid peroxidization triggered by metals $(4,33-35)$.

As a result of chemical analysis of the kernel and shell of the Urfa pistachio nut, it has been determined that the shell contains approximately ten times more phenolic components than the kernel, and the majority of these phenolic components are formed of anthocyanins, and particularly those in the shell show a radical sweeper effect and antioxidant effect $(28,36)$. In a study by Tomaino et al. (5), an analysis was made of the total phenol and flavonoid content of the red shell and the kernel of the peanut plant. The results are shown in the table (Table 1,2).

In an analysis made with High Performance Liquid Chromatography (HPLC), gallic acid, catechin, eriodictyol-7-O-glucoside, naringenin-7-O-neohesperidoside, quercetin- 3-Orutinoside, and eriodictyol components were determined in both the outer shell and the kernel. Genistein-7-O-glucoside, genistein, daidzein, and apigenin components were found in the kernel only and epicatechin, quercetin, naringenin, luteolin, kaempferol, cyanidin-3-O-galactoside, and cyanidin3-O-glucoside in the shell only. In that study, it was shown that the antioxidant activity of the shell was better than that of the kernel, and this was determined to originate from the rate of antioxidant phenolic components and the variety in the content (5). 
In a similar study by Martorana et al. (28), while the majority of anthocyanin, cyanidin-3-O-galactoside, and cyanidin3-O-glucoside components were found in the shell of the Urfa pistachio nut, the epicatechin, aglycones, quercetin, naringenin, luteolin, and kaempferol were determined only in the shell. Gallic acid and catechin were found in much greater amounts in the shell than in the kernel, but isoflavones (genis-

\begin{tabular}{|c|c|c|}
\hline & Seed (kernel) & Shell \\
\hline $\begin{array}{l}\text { Total flavonoid } \\
\text { (mg CatE/g f.w.) }^{\text {a }}\end{array}$ & $0.46 \pm 0.03$ & $70.27 \pm 5.42$ \\
\hline $\begin{array}{l}\text { Total flavonol } \\
\text { (mg QE/g f.w.) }^{\text {b }}\end{array}$ & $0.23 \pm 0.02$ & $0.99 \pm 0.07$ \\
\hline $\begin{array}{l}\text { Total anthocyanin } \\
\text { (mg Cy-G/g f.w.)c }\end{array}$ & Undetermined & $4.86 \pm 0.27$ \\
\hline 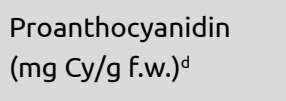 & $1.03 \pm 0.06$ & $27.56 \pm 0.18$ \\
\hline 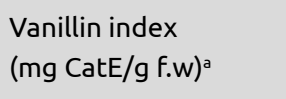 & Undetermined & $16.43 \pm 0.96$ \\
\hline Polymerization index & Undetermined & 0.60 \\
\hline
\end{tabular}

Table 2. Quantitative analysis of the phenolic components of the Pistacia vera L. shell and seed (5)

\begin{tabular}{l|c|c|}
\hline & $\begin{array}{c}\text { Seed (kernel) } \\
\mathrm{mg} / \mathrm{g} \text { (f.w.) }\end{array}$ & $\begin{array}{c}\text { Shell } \\
\mathrm{mg} / \mathrm{g} \text { (f.w.) }\end{array}$ \\
\hline Gallic acid & $12.66 \pm 0.82$ & $1453.31 \pm 97.63$ \\
\hline Catechin & $2.41 \pm 0.18$ & $377.45 \pm 24.36$ \\
\hline Epicathechin & Undetermined & $104.8 \pm 10.56$ \\
\hline Eriodictyol-7-O-glucoside & $31.91 \pm 1.01$ & $365.68 \pm 13.56$ \\
\hline Genistein-7-O-glucoside & $47.02 \pm 1.13$ & Undetermined \\
\hline Naringenin-7-O- & & \\
\hline neohesperidoside & $37.11 \pm 1.25$ & $118.82 \pm 9.64$ \\
\hline Quercetin-3-O-rutinoside & $98.08 \pm 1.54$ & $5.05 \pm 0.02$ \\
\hline Genistein & $69.15 \pm 1.44$ & Undetermined \\
\hline Eriodictyol & $9.37 \pm 0.20$ & $63.17 \pm 1.04$ \\
\hline Daidzein & $42.45 \pm 1.46$ & $\mathrm{~N} . \mathrm{D}$. \\
\hline Quercetin & Undetermined & $17.75 \pm 0.65$ \\
\hline Naringenin & Undetermined & $11.44 \pm 0.90$ \\
\hline Luteolin & Undetermined & $18.97 \pm 0.87$ \\
\hline Kaempferol & Undetermined & $0.95 \pm 0.001$ \\
\hline Apigenin & $0.59 \pm 0.001$ & Undetermined \\
\hline Cyanidin-3-O-galactoside & Undetermined & $5865.12 \pm 362.45$ \\
\hline Cyanidin-3-O-glucoside & Undetermined & $32.56 \pm 4.79$ \\
\hline & & \\
\hline
\end{tabular}

tein, daidzein, genistein-3-O-glucose) were determined only in the kernel (Table 3).

In a study by Ballistreri et al. (37), daidzein, genistein, daidzin, quercetin, eriodictyol, luteolin, genistin, and naringenin flavonoids were determined in all the peanut samples. $\gamma$-tochopherol, which is a major component of Vitamin E,

Table 3. Quantitative phenolic analysis of the Pistacia vera $L$. shell and seed (28)

\begin{tabular}{|c|c|c|}
\hline & $\begin{array}{l}\text { Seed (internal) } \\
\text { mg/g (f.w.) }\end{array}$ & $\begin{array}{c}\text { Shell } \\
\text { mg/g (f.w.) }\end{array}$ \\
\hline Phenolic acids & $113.28 \pm 4.99$ & $5703.22 \pm 382.06$ \\
\hline Gallic acid & $113.28 \pm 4.99$ & $5703.22 \pm 382.06$ \\
\hline Anthocyanins & & \\
\hline - Glycosides N.D. & & $16,606.64 \pm 1036.88$ \\
\hline Cyanidin-3-O-galactoside & & $16,439.32 \pm 1023.55$ \\
\hline Cyanidin-3-O-glucoside & & $167.32 \pm 13.33$ \\
\hline Flavan-3-ols & & \\
\hline - Aglycones & $24.33 \pm 1.74$ & $1932.42 \pm 131.05$ \\
\hline Catechin & $24.33 \pm 1.74$ & $1390.40 \pm 102.59$ \\
\hline $\begin{array}{l}\text { Epicatechin } \\
\text { Isoflavones }\end{array}$ & Undetermined & $542.02 \pm 28.46$ \\
\hline - Aglycones & $876.72 \pm 58.90$ & Undetermined \\
\hline Genistein & $520.93 \pm 30.60$ & \\
\hline Daidzein & $355.79 \pm 28.30$ & \\
\hline - Glycosides & $416.12 \pm 24.33$ & Undetermined \\
\hline $\begin{array}{l}\text { Genistein-7-O-glucoside } \\
\text { Flavanones }\end{array}$ & $416.12 \pm 24.33$ & \\
\hline - Aglycones & $112.26 \pm 3.65$ & $302.50 \pm 18.15$ \\
\hline Eriodictyol & $112.26 \pm 3.65$ & $244.51 \pm 14.89$ \\
\hline Naringenin & Undetermined & $57.99 \pm 3.26$ \\
\hline - Glycosides & $636.51 \pm 52.48$ & $1449.34 \pm 107.07$ \\
\hline Eriodictyol-7-O-glucoside & $274.85 \pm 20.14$ & $1120.66 \pm 83.71$ \\
\hline $\begin{array}{l}\text { Naringenin-7-O- } \\
\text { neohesperidoside } \\
\text { Flavonols }\end{array}$ & $361.66 \pm 32.34$ & $328.68 \pm 23.36$ \\
\hline - Aglycones & Undetermined & $77.19 \pm 3.96$ \\
\hline Quercetin & $71.15 \pm 3.68$ & \\
\hline Kaempferol & $6.04 \pm 0.28$ & \\
\hline - Glycosides & $874.11 \pm 44.55$ & $28.53 \pm 4.96$ \\
\hline $\begin{array}{l}\text { Quercetin-3-O-rutinoside } \\
\text { Flavones }\end{array}$ & $874.11 \pm 44.55$ & $28.53 \pm 4.96$ \\
\hline - Aglycones & $8.01 \pm 0.08$ & $85.14 \pm 4.93$ \\
\hline Luteolin & $85.14 \pm 4.93$ & \\
\hline Apigenin & $8.01 \pm 0.08$ & \\
\hline
\end{tabular}


was found in ripe red and unripe green peanuts, and it was determined that $\alpha$ - and $\gamma$-tochopherol decreased together with ripening and drying. In the light of these results, it was suggested that unshelled peanuts are a rich nutritional source of phenolic components, especially of anthocyanin.

In a study by Gentile et al. (4) of Urfa pistachio nut kernels, while it was determined that isoflavones were not changed before peeling, the active components were significantly reduced after peeling, and the antioxidant activity was observed to reduce by $60 \%$.

In an analysis of the essential oil content of Urfa pistachio nut plant leaves and fruit made with GC and GC/MS, it was determined that the fresh unripened nuts were richer $(0.5 \%)$ than the leaves $(0.1 \%)$.

\section{3) Studies Related to Anti-cancer Properties}

Due to the terpenes and phenolic components contained in the lipophyllic extracts and essential oils obtained from the leaves, fruit, gum, and resins of Pistacia species (P. lentiscus, P. terbintus, $P$. vera), effects have been determined such as antioxidant, antitumour, antimicrobial, anti-inflammatory, insecticidal, and antinociceptive effects $(2,38-43)$. In some studies, in an in vitro environment, the extract obtained from the gum of $P$. Lentiscus has been determined to direct human colorectal tumour cells to apoptosis and prevent proliferation (44). Furthermore, an antitumour effect has been shown with delayed growth of colorectal tumors developed in mice (45), resin has shown a cytotoxic effect against promyelocytic leukemia (46), and prostate cancer cells $(47,48)$.

In recent studies, the extract obtained from the fruit of $P$. atlantica showed growth inhibition similar to doxirubicin in human colon carcinoma cells (49), and oleoresin obtained from the resin of $P$. vera $L$. was determined to show a cytotoxic effect against hepatocellular carcinoma, cervical cancer, and melanocyte cells (50). In another study, the metabolite pure substances in the ethanol extract, obtained from the soft outer shell of the fruit of $P$. vera $L$., showed a cytoxic effect by various rates of inhibition against the PVK-3 (anacardol 15:1), PVK-6 (anacardic acid 13:1), and PVK-8 (shikimic acid) A549 cancer cell lines (51).

Digallic acid (DGA), which is a purified from the Pistacia fruit was investigated with respect to antiproliferative and apoptotic activity on human lymphoblastoid TK6 cells, and the study results showed that DGA had a potential as a protective substance by showing an apoptosis inductor effect on the TK6 cells (52).

\section{4) Studies Related to Antimicrobial Efficacy}

While the lipophyllic extracts obtained from the red outer shell covering and the inner kernel of the Urfa pistachio show a low antibacterial effect, a significant degree of antifungal activity and antiviral effects have been shown against $C$. albicans and C. parapsilosis fungi (42).
In studies made with respect to the growth inhibition effect on 13 bacteria and three yeast species of the essential oils obtained from the Urfa pistachio resin, with the exception of Bacillus cereus, Pseudomonas aeruginosa, and Klebsiella pneumonia, an antimicrobial effect was seen in all otherbacteria and yeast species, and it was determined that it could be used even more effectively than nystatin, which is used effectively in the treatment of yeast infections $(2,53)$.

The antimicrobial activity of the foodstuff product of the polyphenol-rich extract obtained from raw shelled Urfa pistachio nuts and roasted nuts was investigated on Gram-negative and Gram-positive bacteria and some fungal species. It was determined that the extract showed a bactericidal effect against Listeria monocytogenes, Staphylococcus aureus, and methycillin-resis$\operatorname{tant} S$. aureus. Thus, it was suggested that the pistachio extract increased food safety by providing a control of the proliferation of some microorganisms in food products and that it could also be used in topical treatment of $S$. aureus. (54).

\section{Conclusion}

As the Urfa pistachio nut has antioxidant, anti-inflammatory, lipid regulatory, anti-cancer, antimicrobial, and antifungal properties, and it provides protection against cardiovascular diseases, there have been several reports stating that the intake in the daily diet would provide a significant protective effect for human health and protection from various pathological conditions (5).

As the Urfa pistachio nut is generally eaten raw as a snack, roasted, or processed (e.g., in baklava, chocolate, ice-cream, meat processing), the useful outer shell is discarded. The outer shell contains approximately ten times more phenolic components, especially anthocyanin, than the kernel, and these components show a radical sweeper effect and antioxidant properties $(28,36,55-57)$. The outer shell extract, which has a protective effect against the UV-B-origin skin damage in particular, is a protective substance that can be used in topical cosmetic and medication formulations (28).

The outer shell of the Urfa pistachio nut, which has antibacterial, antifungal, antiprotozoal, and antiviral effects (42, 43, $53,54)$, should not be seen as a waste product. In a study related to antiprotozoal efficacy, the extract obtained from the fruit of $P$. vera $L$. showed a cytoxic effect against Leishmania donovani, and the extract obtained from the leaves showed a cytotoxic effect against Plasmocium falciparum, and neither had any effect on normal cells $(43,56)$.

The shells discarded after industrial processing constitute $10 \%$ of the weight of the whole nuts (5). In Turkey, an average of 107,300 tons of Urfa pistachio nuts are produced per annum, which means 10,730 tons of waste from this production. Moreover, the waste after industrial processing causes environmental pollution. Unfortunately, these plant parts that contain antioxidants and perhaps many more important components as yet undetermined, are treated as agricultural waste as they cannot be evaluated. By drawing attention to this area with this review, 
it was aimed to create awareness for the transformation of these valuable plant parts treated as agricultural waste to products that could contribute to the national economy.

Peer-review: Externally peer-reviewed.

Author Contributions: Concept - İ.K., A.K., R.D., Ş.S.; Design H.K.Ö., İ.K., A.K., R.D., Ş.S.; Supervision - İ.K., A.K., R.D., Ş.S.; Resources - İ.K., A.K., R.D., Ş.S.; Literature Search - İ.K., A.K., R.D., Ş.S.; Writing Manuscript - İ.K., A.K., R.D., Ş.S.; Critical Review - İ.K., A.K.

Conflict of Interest: The authors have no conflicts of interest to declare.

Financial Disclosure: The authors declared that this study has received no financial support.

Hakem Değerlendirmesi: Dış bağımsız.

Yazar Katkıları: Fikir - İ.K., A.K., R.D., Ş.S.; Tasarım - H.K.Ö., İ.K., A.K., R.D., Ş.S.; Denetleme - İ.K., A.K., R.D., Ş.S.; Kaynaklar - İ.K., A.K., R.D., Ş.S.; Literatür Taraması - İ.K., A.K., R.D., Ş.S.; Yazıyı Yazan - İ.K., A.K., R.D., Ş.S.; Eleştirel İnceleme - İ.K., A.K.

Çıkar Çatışması: Yazarlar çıkar çatışması bildirmemişlerdir.

Finansal Destek: Yazarlar bu çalışma için finansal destek almadıklarını beyan etmişlerdir.

\section{References}

1. Dreher Mark L. Pistachio nuts: composition and potential health benefits. Nutr Rev 2012; 70: 234-40. [CrossRef]

2. Alma MH, Nitz S, Kollmannsberger H, Digrak M, Efe FT, Yilmaz N. Chemical composition and antimicrobial activity of the essential oils from the gum of Turkish pistachio (Pistacia vera L.). J Agric Food Chem 2004; 52: 3911-4. [CrossRef]

3. Bozorgi M, Memariani Z, Mobli M, SalehiSurmaghi MH, Shams-Ardekani MR, Rahimi R. Five Pistacia species (P. vera, P. atlantica, P. terebinthus, P. khinjuk, and P. lentiscus): a review of their traditional uses, phytochemistry, and pharmacology. ScientificWorldJournal 2013; 2013: 219815. [CrossRef]

4. Gentile C, Tesoriere L, Butera D, Fazzari M, Monastero M, Allegra M, et al. Antioxidant activity of Sicilian pistachio (Pistacia vera L. var. Bronte) nut extract and its bioactive components. J Agric Food Chem 2007; 55: 643-8. [CrossRef]

5. Tomaino A, Martorana M, Arcoraci T, Monteleone D, Giovinazzo C, Saija A. Antioxidant activity and phenolic profile of pistachio (Pistacia vera L., variety Bronte) seeds and skins. Biochimie 2010; 92: 1115-22. [CrossRef]

6. Bolling BW, McKay DL, Blumberg JB. The phytochemical composition and antioxidant actions of tree nuts. Asia Pac J Clin Nutr 2010; 19: 117-23.

7. Seeram NP, Zhang Y, Henning SM, Lee R, Niu Y, Lin G, et al. Pistachio skin phenolics are destroyed by bleaching resulting in reduced antioxidative capacities. J Agric Food Chem 2006; 54: 7036-40. [CrossRef]

8. Wu X, Prior RL. Identification and characterization of anthocyanins by high-performance liquid chromatography-electrospray ionization-tandem mass spectrometry in common foods in the United States: vegetables, nuts, and grains. J Agric Food Chem 2005; 53: 3101-13. [CrossRef]

9. Basaria S., A. Wisniewski, K. Dupree, Effect of high-doseisoflavones on cognition, quality of life, androgens, andlipoprotein in post-menopausalwomen. J Endocrinol Invest 2009; 32: 1505. [CrossRef]

10. Morton LW, Abu-Amsha Caccetta R, Puddey IB, Croft KD. Chemistry and biological effects of dietary phenolic compounds: relevance to cardiovascular disease. Clin Exp Pharmacol Physiol 2000; 27: 152-9. [CrossRef]

11. Kris-Etherton PM, Hecker KD, Bonanome A, Coval SM, Binkoski AE, Hilpert KF, et al. Bioactive compounds in foods: their role in the prevention of cardiovascular disease and cancer. Am J Med 2002; 113(Suppl 9B): 71S-88S. [CrossRef]

12. Chen CY, Milbury PE, Lapsley K, Blumberg JB. Flavonoids from almond skins are bioavailable and act synergistically with vitamins $\mathrm{C}$ and $\mathrm{E}$ to enhance hamster and human LDL resistance to oxidation. J Nutr 2005; 135: 1366-73. [CrossRef]

13. Edwards K, Kwaw I, Matud J, Kurtz I. Effect of pistachio nuts on serum lipid levels in patients with moderate hypercholesterolemia. J Am Coll Nutr 1999; 18: 229-32. [CrossRef]

14. Kocyigit A, Koylu AA, Keles H. Effects of pistachio nuts consumption on plasma lipid profile and oxidative status in healthy volunteers. Nutr Metab Cardiovasc Dis 2006; 16: 202-9. [CrossRef]

15. Sheridan MJ, Cooper JN, Erario M, Cheifetz CE. Pistachio nut consumption and serum lipid levels. J Am Coll Nutr 2007; 26: 141-8. [CrossRef]

16. Gebauer SK, West SG, Kay CD, Alaupovic P, Bagshaw D, KrisEtherton PM. Effects of pistachios on cardiovascular disease risk factors and potential mechanisms of action: a dose-response study. Am J Clin Nutr 2008; 88: 651-9. [CrossRef]

17. Sari I, Baltaci Y, Bagci C, Davutoglu V, Erel O, Celik H, et al. Effect of pistachiodiet on lipidparameters, endothelialfunction, inflammation, andoxidativestatus: a prospectivestudy. Nutrition 2010; 26: 399-404. [CrossRef]

18. Kay CD, Gebauer SK, West SG, Kris-Etherton PM. Pistachios increase serum antioxidants and lower serum oxidized-LDL in hypercholesterolemic adults. J Nutr 2010; 140: 1093-8. [CrossRef]

19. Kinlay S, Egido J. Inflammatory biomarkers in stable atherosclerosis. Am J Cardiol 2006; 98: 2P-8P. [CrossRef]

20. Packard RR, Libby P. Inflammation in atherosclerosis: from vascular biology to biomarker discovery and risk prediction. Clin Chem 2008; 54: 24-38. [CrossRef]

21. Wilson PW. Evidence of systemic inflammation and estimation of coronary artery disease risk: a population perspective. Am J Med 2008; 121: S15-20. [CrossRef]

22. Alturfan AA, Alturfan EE, Uslu E. Pistachio consumption has beneficial effects on diabetic rat model. F.Ü. Sağ Bil Tip Derg 2009; 23: 131-5.

23. Phillips KM, Ruggio DM, Ashraf-Khorassani M. Phytosterol composition of nuts and seeds commonly consumed in the United States. J Agric Food Chem 2005; 53: 9436-66. [CrossRef]

24. Segura R, Javierre C, Lizarraga MA, Ros E. Other relevant components of nuts: phytosterols, folate and minerals. Br J Nutr 2006; 96(Suppl 2): S36-44. [CrossRef]

25. US Department of Agriculture, AgriculturalResearch Service. USDA NationalNutrient Database forStandard Reference, Release 24. Pistachios (dryroasted, with salt added) (NDB no. 
12652), almonds (raw [NDB no. 12061], blanched [NDB no. 12062], dryroasted, with salt added [NDB no. 12563]), walnuts (English) (NDB no. 12155). Beltsville, MD: AgriculturalResearch Service, US Dept of Agriculture; 2011. Available at: http://ndb.nal.usda.gov/ndb/foods/list. Accessed 11 February 2012.

26. Khaw KT, Thom S. Randomised double-blind cross-over trial of potassium on blood-pressure in normal subjects. Lancet 2001; 982: 1127-9.

27. Chang HY, Hu YW, Yue CS. Effect of potassium-enriched salt on cardiovascular mortality and medical expenses of elderly men. Am J Clin Nutr 2006; 83: 1289-96. [CrossRef]

28. Martorana M, Arcoraci T, Rizza L, Cristani M, Bonina FP, Saija A, et al. In vitro antioxidant and in vivo photoprotective effect of pistachio (Pistacia vera L., variety Bronte) seed and skin extracts. Fitoterapia 2013; 85: 41-8. [CrossRef]

29. Messina MJ, Persky V, Setchell KD, Barnes S. Soy intake and cancer risk: a review of the in vitro and in vivo data. Nutr Cancer 1994; 21: 113-31. [CrossRef]

30. Bowers JL, Tyulmenkov VV, Jernigan SC, Klinge CM. Resveratrol acts as a mixed agonist/antagonist for estrogen receptors alpha and beta. Endocrinology 2000; 141: 3657-67. [CrossRef]

31. Sovak M. Grapeextract, resveratrol, anditsanalogues: A review. J Med Food 2001; 4: 93-105. [CrossRef]

32. Tokuşoglu O, Unal MK, Yemiş F. Determination of the phytoalexin resveratrol $\left(3,5,4^{\prime}\right.$-trihydroxystilbene) in peanuts and pistachios by high-performance liquid chromatographic diode array (HPLC-DAD) and gas chromatography-mass spectrometry (GC-MS). J Agric Food Chem 2005; 53: 5003-9. [CrossRef]

33. Hammerstone JF, Lazarus SA, Schmitz HH. Procyanidin content and variation in some commonly consumed foods. J Nutr 2000; 130(8S Suppl): 2086S-92S.

34. Dixon RA, Xie DY, Sharma SB. Proanthocyanidins--a final frontier in flavonoid research? New Phytol 2005; 165: 9-28. [CrossRef]

35. Venkatachalam M, Sathe SK. Chemical composition of selected edible nut seeds. J Agric Food Chem 2006; 54: 4705-14. [CrossRef]

36. Tsao R. Chemistry and biochemistry of dietary polyphenols. Nutrients 2010; 2: 1231-46. [CrossRef]

37. Ballistreri G, Arena E, Fallico B. Influence of ripeness and drying process on the polyphenols and tocopherols of Pistacia vera L. Molecules 2009; 14: 4358-69. [CrossRef]

38. Giner-Larza EM, Máñez S, Giner RM, Recio MC, Prieto JM, Cerdá-Nicolás $M$, et al. Anti-inflammatory triterpenes from Pistacia terebinthus galls. Planta Med 2002; 68: 311-5. [CrossRef]

39. Giner-Larza EM, Máńez S, Recio MC, Giner RM, Prieto JM, Cerdá-Nicolás $\mathrm{M}$, et al. Oleanonic acid, a 3-oxotriterpene from Pistacia, inhibits leukotriene synthesis and has anti-inflammatory activity. Eur J Pharmacol 2001; 428: 137-43. [CrossRef]

40. Duru ME, Cakir A, Kordali S, Zengin H, Harmandar M, Izumi $S$, et al. Chemical composition and antifungal properties of essential oils of three Pistacia species. Fitoterapia 2003; 74: 170-6. [CrossRef]

41. Koutsoudaki C, Krsek M, Rodger A. Chemical composition and antibacterial activity of the essential oil and the gum of Pistacia lentiscus Var. chia. J Agric Food Chem 2005; 53: 7681-5. [CrossRef]
42. Ozçelik B, Aslan M, Orhan I, Karaoglu T. Antibacterial, antifungal, and antiviral activities of the lipophylic extracts of Pistacia vera. Microbiol Res 2005; 160: 159-64. [CrossRef]

43. Orhan I, Küpeli E, Aslan M, Kartal M, Yesilada E. Bioassayguided evaluation of anti-inflammatory and antinociceptive activities of pistachio, Pistacia vera L. J Ethnopharmacol 2006; 105: 235-40. [CrossRef]

44. Sakagami H, Kishino K, Kobayashi M, Hashimoto K, Iida S, Shimetani A, et al. Selective antibacterial and apoptosis-modulating activities of mastic. In Vivo 2009; 23: 215-23.

45. Dimas K, Hatziantoniou S, Wyche JH, Pantazis P. A mastic gum extract induces suppression of growth of human colorectal tumor xenografts in immunodeficient mice. In Vivo 2009; 23: 63-8.

46. Balan KV, Prince J, Han Z, Dimas K, Cladaras M, Wyche JH, et al. Antiproliferative activity and induction of apoptosis in human colon cancer cells treated in vitro with constituents of a product derived from Pistacia lentiscus L. var. chia. Phytomedicine 2007; 14: 263-72. [CrossRef]

47. He ML, Chen WW, Zhang PJ, Jiang AL, Fan W, Yuan HQ, et al. Gum mastic increases maspin expression in prostate cancer cells. Acta Pharmacol Sin 2007; 28: 567-72. [CrossRef]

48. He ML, Li A, Xu CS, Wang SL, Zhang MJ, Gu H, et al. Mechanisms of antiprostate cancer by gum mastic: NF-kappaB signal as target. Acta Pharmacol Sin 2007; 28: 446-52. [CrossRef]

49. Rezaei PF, Fouladdel S, Hassani S, Yousefbeyk F, Ghaffari SM, Amin G, et al. Induction of apoptosis and cell cycle arrest by pericarp polyphenol-rich extract of Baneh in human colon carcinoma HT29 cells. Food Chem Toxicol 2012; 50: 1054-9. [CrossRef]

50. Almehdar H, Abdallah HM, Osman AM, Abdel-Sattar EA. In vitro cytotoxic screening of selected Saudi medicinal plants. J Nat Med 2012; 66: 406-12. [CrossRef]

51. Gokdemir G, P. vera L. kuru kırmızı kabuğunun fitokimyasal bileşimi ve saflaştırılan sekonder metabolitlerin anti tümör özelliklerinin araştırılması, Yüksek lisans tezi, 2016.

52. Bhouri W, Boubaker J, Skandrani I, Ghedira K, Chekir Ghedira L. Investigation of the apoptotic way induced by digallic acid in human lymphoblastoid TK6 cells. Cancer Cell Int 2012; 12: 26. [CrossRef]

53. Ramezani M, Khaje-Karamoddin M, Karimi-Fard V. Chemical composition and anti-Helicobacter pylori activity of theessential oil of Pistacia vera. Pharm Biol 2004; 42: 488-90. [CrossRef]

54. Bisignano C, Filocamo A, Faulks RM, Mandalari G. In vitro antimicrobial activity of pistachio (Pistacia vera L.) polyphenols. FEMS Microbiol Lett 2013; 341: 62-7. [CrossRef]

55. Erşan S, Güçlü Üstündağ Ö, Carle R, Schweiggert RM. Identification of Phenolic Compounds in Red and Green Pistachio (Pistacia vera L.) Hulls (Exo- and Mesocarp) by HPLC-DADESI-(HR)-MS(n). J Agric Food Chem 2016; 64: 5334-44. [CrossRef]

56. Mahmoudvand H, Saedi Dezaki E, Ezatpour B, Sharifi I, Kheirandish F, Rashidipour M. In Vitro and In Vivo Antileishmanial Activities of Pistacia vera Essential Oil. Planta Med 2016; 82: 279-84. [CrossRef]

57. Barreca D, Laganà G, Leuzzi U, Smeriglio A, Trombetta D, Bellocco E. Evaluation of the nutraceutical, antioxidant and cytoprotective properties of ripe pistachio (Pistacia vera L., variety Bronte) hulls. Food Chem 2016; 196: 493-502. [CrossRef] 